\title{
PENGARUH LEVERAGE DAN UKURAN PERUSAHAAN TERHADAP NILAI PERUSAHAAN DI INDONESIA
}

\author{
Halim Tri Rejeki ${ }^{1}$ \\ Universitas Islam Negeri Sunan Kalijaga,Yogyakarta \\ Email:alimatusyifa@gmail.com \\ Slamet Haryono ${ }^{2}$ \\ Universitas Islam Negeri Sunan Kalijaga, Yogyakarta \\ Email: slamet.haryono@uin-suka.ac.id
}

\begin{abstract}
This study aims to examine the effect of leverage and company size on firm value, which in this study uses the Price to Book Value (PBV) measure which is a ratio that indicates whether the valuation is overvalued (above or below the valuation (below the book value of shares is the stock price can be traded) Firm value is one of the indicators of company performance appraisal in general. In addition, company value is also a consideration for investors who will invest. The population in this study is the mining and agricultural sub-sector companies listed on the Indonesia Stock Exchange. (BEI) 20132018. The sampling technique used purposive sampling, namely the selection of samples based on certain criteria according to what the researchers wanted. The number of samples used in this study were 7 (seven) companies with six years of observation, so that 42 data were selected. observation.Data used is secondary data in the form of the company's annual financial statements obtained from the Indonesia Stock Exchange (IDX). The data analysis technique in this research is descriptive statistics and panel data analysis. The software used for data processing is Eviews 2010 and excel. The test results show that, only the leverage variable has an effect and is in accordance with the theory, this is because the company data used has a large difference in total assets.
\end{abstract}

Keywords: Price to Book Value, Firm Value, Leverage, Company Size

\begin{abstract}
Abstrak
Penelitian ini bertujuan untuk menguji pengaruh leverage dan ukuran perusahaan terhadap nilai perusahaan, yang dalam penelitian menggunakan ukuran Price to Book Value (PBV) merupakan rasio yang menunjukkan apakah penilaian berlebihan (di atas atau di bawah penilaian (di bawah nilai buku saham adalah harga saham yang dapat diperdagangkan). Nilai perusahaan merupakan salah satu indikator penilaian kinerja perusahaan secara umum. Selain itu, nilai perusahaan juga menjadi salah satu pertimbangan bagi para investor yang akan menanamkan modalnya. Populasi dalam penelitian ini adalah perusahaan subsektor pertambangan dan pertanin yang terdaftar di Bursa Efek Indonesia (BEI) tahun 2013-2018. Teknik pengambilan sampel menggunakan purposive sampling, yaitu pemilihan sampel berdasarkan kriteria tertentu sesuai dengan yang diinginkan peneliti. Jumlah sampel yang digunakan dalam penelitian ini adalah 7 (tujuh) perusahaan dengan observasi selama enam tahun, sehingga terpilih 42 data observasi. Data yang digunakan adalah data sekunder berupa laporan keuangan tahunan perusahaan yang diperoleh dari Bursa Efek Indonesia (BEI). Teknik analisis data dalam penelitian ini adalah statistik deskriptif dan analisis data panel. Perangkat lunak yang digunakan untuk pengolahan data adalah Eviews 2010 dan excel. Hasil pengujian menunjukkan bahwa, hanya vareabel leverage yang berpengaruh dan sesuai dengan teori, hal ini disebabkan karena data perusahaan yang digunakan memiliki perbedaan selisih total aset yang besar.
\end{abstract}

Kata Kunci: Price to Book Value, Nilai Perusahaan, leverage, Ukuran Perusahaan 


\section{PENDAHULUAN}

Memaksimalkan

kekayaan

pemegang saham, merupakan salah satu tujuan didirikannya perusahaan, yang dapat dicapai dengan mengoptimalkan niai perusahaan. Pada perusahaan yang go public, pemaksimalan nilai harga saham menjadi salah satu syarat penting untuk mencapai tujuan tersebut (Aggarwal \& Padhan, 2017; Nguyen et al., 2019; Ibrahim, 2020; Etty et al., 2020). Kenaikkan harga saham dapat meningkatan kesejahteraan para pemegang sahamnya (; Yuniningsih et al., 2019; Ibrahim, 2020 Etty et al., 2020). Oleh karena itu, tingginya nilai dari perusahaan pada akhirnya dapat meningkatkan kredibilitas untuk investor. Pemodal harus yakin akan informasi yang benar. Diperlukannya kepercayaan dan tidak memanipulasi informasi dalam sistem perdagangan yang ada. Pemodal tentu takut untuk membeli sekuritas yang ditawarkan oleh perusahaan (atau diperdagangkan di bursa) tanpa kepercayaan (Nguyen, 2018).

Pertumbuhan jumlah perusahaan yang tercatat di Bursa Efek Indonesia semakin tinggi yakni mencapai 700 perusahaan (BEI, 2020). Pertumbuhan tersebut didorong oleh beberapa aspek, diantaranya adalah peran aktif pemerintah yang memberikan fasilitas dalam kemudahan berinvestasi, kemudahan akses listing dan semakin banyaknya perusahaan yang bermain aktif di pasar saham, tentunya diharapkan mampu menjadi peluang besar bagi Indonesia untuk mencapai pertumbuhan ekonomi (Etty et a., 2020).

Nilai perusahaan dapat diukur dengan leverage keuangan dan ukuran perusahaan. Kedua hal tersebut menjadi masalah penting, serta menjadi perhatian manajer keuangan sebagai akibat dari perkembangan besar yang dialami pasar keuangan dan perkembangan teknologi (Zaher, 2020). Pengambilan keputusan yang sulit oleh seorang manajer adalah pada financial leverage, karena kenaikan rasio hutang dapat meningkatkan risiko keuangan dan mengakibatkan kenaikan biaya modal (Noghondari \& Noghondari, 2017). Sehingga, perusahaan harus mampu memanfaatan sumber daya keuangan untuk mencapai profitabilitas yang diharapkan (Zaher, 2020). Apabila tidak maka besarnya leverage sebuah perusahaan akan mampu menurunkan nilai suatu perusahaan (Etty, 2020).

Vareabel selanjutnya yakni ukuran perusahaan, yang dalam beberapa penelitian memiliki pengaruh positif terhadap nilai perusahaan. Ukuran perusahaan merupakan salah satu variabel yang dapat menentukan nilai perusahaan. Besar kecilnya perusahaan dapat menjelaskan jumlah total aset yang dimiliki perusahaan. Ketika ukuran perusahaan besar, maka aset yang dimiliki oleh perusahaan juga semakin signifikan, dan dana yang dibutuhkan oleh perusahaan untuk mengoperasikan semakin signifikan (Aggarwal \& Padhan, 2017; Etty et al., 2020).

Penelitian ini dilakukan untuk menganalisis bagaimana pengaruh kedua vareabel tersebut di perusahaan pertambangan dan Pertanian tahun 2013-2018 yang terdaftar di Bursa Efek Indonesia dan memiliki data yang lengap, yang sesuai dengan data yang dibutuhkan oleh peneliti.

\section{TINJAUAN PUSTAKA}

\subsection{Teori Agensi}

Teori keagenan adalah teori yang membahas hubungan yang terjadi antar pemegang saham, sebagai pemilik perusahaan (principal) dengan para 
manajemen sebagai agen. Dimana pengelolaan saham menjadi tanggung jawab manjemen, yang sekaligus juga menjalankan perusahaan untuk mencapai tujuan perusahaan. Akan tetapi, pada prakteknya sering terjadi konflik (konflik keagenan) karena pihak pemegang saham dan agen memiliki kepentingan yang bertentangan (Perdana \& Raharja, 2014; Reschiwati at al., 2020).

\subsection{Teori trade-off}

Teori trade-off leverage adalah teori yang menjelaskan bahwa struktur modal yang optimal ditemukan dengan menyeimbangkan manfaat dari pembiayaan hutang (perlakuan pajak perusahaan yang menguntungkan) dengan tingkat suku bunga yang lebih tinggi dan kebangkrutan (Brigham dan Houston, 2011; Hirdinis, 2019).

\subsection{Teori Persinyalan (Signaling theory)}

Teori persinyalan adalah suatu kegiatan yang dilakukan oleh pengelola untuk mengarahkan pemilik tentang bagaimana caranya manajemen melihat masa depan perusahaan, yang berupa rincian tentang apakah manajemen telah melakukan tugasnya untuk memenuhi keinginan pemilik saham. Jensen \& Meckling, mendefinisikan Signaling teori (Bouzzine dan Lueg 2020; Brown dkk. 2020; Shahrbabaki dkk. 2020; Shou dkk. 2020; Y. Wang et al. 2020; Zuo, Weng, dan Xie 2020; Kalbuana, 2020). Sinyal tersebut dapat berupa informasi yang menyatakan bahwa perusahaan tersebut lebih baik dari pada perusahaan lain (Doukas dan Zhang 2020; Javed dkk. 2020). Karena pengaruhnya terhadap keputusan investasi di luar bisnis, maka pengetahuan yang diterima organisasi merupakan hal yang penting. Informasi itu penting untuk investor karena informasi yang disampaikan langsung dalam bentuk nota atau ringkasan sejarah, untuk kelangsungan hidup saat ini dan masa depan perusahaan serta dampaknya terhadap perusahaan (Kalbuana, 2020).

\subsection{Nilai Perusahaan}

Tingkat keberhasilan suatu perusahaan yang terkait erat dengan harga saham perusahaan adalah nilai perusahaan itu sendiri (Kalbuana, 2020). Nilai perusahaan tinggi juga tidak terlepas dari harga saham yang tinggi pula, karena akan meningkatan kepercayaan di pasar, yang tidak hanya dilihat pada kinerja perusahaan saat ini saja, tetapi juga prospek perusahaan masa depan (Cabaleiro-Cerviño dan Burcharth 2020; Kalbuana, 2020)

Pengukuran nilai perusahaan bermacam-macam diantaranya yakni menggunakan rumus Price to Book Value (PBV) (Baldick dan Jung 2020). Apresiasi pasar atas nilai buku saham suatu perusahaan dapat ditunjukan melalui PBV, dimana apabila rasio semakin tinggi, maka masa depan bisnis dapat didedikasikan melalui pasar. PBV juga merupakan rasio yang menunjukkan apakah penilaian berlebihan (di atas atau di bawah penilaian (di bawah nilai buku saham adalah harga saham yang dapat diperdagangkan). Selain itu, dapat mengungkapkan jumlah penilaian yang relatif tinggi yang akan dihasilkan suatu bisnis dengan jumlah uang yang dibelanjakan (Moore, 2020).

Para investor akan memilih perusahaan untuk menginvestasikan modalnya pada perusahaan dengan nilai perusahaan yang baik, karena semakin tinggi keuntungan yang diperoleh dan semakin banyak laba bersih yang diperoleh investor. Demikian adalah ukuran presepsi investor mengenai 
tingat kualitas perusahaan (Sujoko \& Soebiantoro, 2017; Etty, 2020).

\subsection{Leverage}

Tingkat hutang pembiayaan suatu perusahaan dapat diukur dengan menggunaan Leverage. Penggunaan utang pada perusahaan akan beresiko pada biaya bunga yang menjadi beban yang harus dibayar oleh perusahaan. Semakin besar nilai leverage perusahaan, semakin tinggi pula biaya bunga hutang yang harus dibayar oleh perusahaan, akibatnya nilai perusahaan menjadi berkurang (Etty at al., 2020).

\subsection{Ukuran Perusahaan}

Semakin besar ukuran perusahaan, semakin mudah perusahaan mendapatkan sumber pendanaan (Reschiwati, 2020). Ketika perusahaan mengalami masa pertumbuhan, dimana hal ini akan mendorong respon positif para investor dan tentunya akan meningkatan niai perusahaan. Hal tersebut tidak terlepas dari ukuran perusahaan yang besar (Hardinis, 2019).

Ukuran perusahaan yang lebih besar memiliki beberapa keunggulan diantaranya yakni, menunjukan total aset perusahaan yang besar pula, semakin mudah untuk mendapatkan pendanaan, baik eksternal maupun internal dan memiliki sensitivitas yang lebih besar dan transfer kekayaan yang relatif besar, jika dibandingkan dengan perusahaan yang berukuran kecil. Oleh karena itu penjualan saham semakin tinggi, maka semakin cepat uang sampai ke perusahaan. Dimana, ukuran perusahaan atau jumlah aset perusahaan mampu mencerminkan ukuran perusahaan (Horne dan Wachowicz, 2009; Hardinis, 2019).

Ukuran perusahaan merupakan cerminan dari ukuran yang muncul pada nilai total aset perusahaan. Investor memiliki ekspektasi yang besar terhadap perusahaan besar dan memiliki ekspektasi yang besar terhadap dividen dari perusahaan tersebut. Semakin besar ukuran perusahaan maka semakin besar pula kecenderungan investor untuk memiliki sahamnya, sehingga akan mengakibatkan kenaikan harga saham. Kenaikan harga saham akan menyebabkan kenaikan harga buku value (PBV) atau nilai perusahaan. Perusahaan besar dapat menyebabkan pasar bersedia membayar lebih untuk sahamnya karena mereka yakin akan mendapatkan keuntungan yang menguntungkan dari perusahaan (Brealey et al., 2011; Hirdinis, 2019).

Berdasarkan uraian tersebut, hipotesis dalam penelitian ini adalah;

\section{H1 :Leverage berpengaruh negatif terhadap nilai perusahaan.}

\section{H2 :Size berpengaruh positif terhadap nilai perusahaan.}

\section{METODE PENELITIAN}

Penelitian ini merupakan penelitian kausal yang bertujuan untuk mengetahui pengaruh variabel independen terhadap variabel dependen dengan studi kuantitatif. Populasi penelitian ini adalah seluruh perusahaan pertanian dan pertamabangan yang terdaftar di Bursa Efek Indonesia (BEI). Sampel penelitian adalah 7 perusahaan. Data sekunder dalam penelitian ini dikumpulkan dari laporan keuangan tahunan perusahaan yang diperoleh dari Bursa Efek Indonesia (BEI).

\subsection{Metode Analisis Data}

Dalam penelitian ini data yang digunakan adalah data panel. Uji regresi data panel ini digunakan untuk 
mengetahui hubungan antara variabel independen yang terdiri dari laverege dan ukuran perusahaa.

Model regresi data panel dalam penelitian ini sebagai berikut:

PBVit $=\alpha+$ LEVX1it + SIZEX2it + eit

Keterangan:

\begin{tabular}{|l|l|l|}
\hline Vareabel & $\begin{array}{l}\text { Acronym } \\
\text { s }\end{array}$ & Pengukuran \\
\hline $\begin{array}{l}\text { Price To } \\
\text { Boo } \\
\text { Value } \\
\text { (Y) }\end{array}$ & PBV & $\begin{array}{l}\text { (Harga } \\
\text { Saham)/juml } \\
\text { ah ekuitas / } \\
\text { Jumah saham } \\
\text { beredar) }\end{array}$ \\
\hline $\begin{array}{l}\text { Ukuran } \\
\text { perusahaa } \\
\text { n (X1) }\end{array}$ & SIZE & $\begin{array}{l}\text { Logaritma } \\
\text { natural dari } \\
\text { penjualan } \\
\text { nyata }\end{array}$ \\
\hline $\begin{array}{l}\text { Leverage } \\
\text { (X2) }\end{array}$ & LEV & $\begin{array}{l}\text { Total hutang } \\
\text { dibagi dengan } \\
\text { total aset }\end{array}$ \\
\hline
\end{tabular}

Tahapan analisis data untuk menganalisis data penel diperlukan uji spesifikasi model yang tepat untutk memilih salah satu cara dari tiga pendekatan (Amyulianthy \& Elsa, 2016: 10). Pertama memilih antara Common Effect Model vs Fixed Effect Model, dengan cara memilih modal mana yang lebih cocok antara keduanya, yaitu dengan menggunakan Uji Chow (Uji F terbatas). Kedua, memilih antara Fixed Effect Model vs Random Effect Model, yaitu memilih mana yang lebih cocok antara keduanya, dengan cara menggunakan uji Hausman Test. Ketiga, memilih antara Common Effect Model vs Random Effect Model, dengan cara memilih model mana yang lebih cocok antara kedua, yaitu dengan menggunakan Lagrange Multiplier Test (LM Test).

Setelah memilih model yang tepat, dilanjutkan dengan uji asumsi klasik yaitu uji normalitas, uji multikolineartias, uji heteroskedastisitas dan uji autokorelasi. Setelah tahap uji asumsi klasik dilanjutkan dengan uji statistik diantaranya adalah uji koefisien determinasi, uji simultan, dan uji parsial.

\section{HASIL DAN PEMBAHASAN}

\subsection{Uji Hipotesis dan Pemilihan Model}

Sebelum melakukan uji hipotesis, diperlukan untuk memilih model yang tepat dari uji data panel dengan menggunakan Uji Chow, Uji Hausman, dan Uji LM. Berdasarkan uji pemilihan model pada penelitian ini, model yang paling baik adalah Model Fixed Effect (FEM), namun pada uji asumsi klasik, model penelitian terdapat masalah heteroskedastisitas dan autokorelasi. Sehingga, model yang paling tepat adalah model Generalized Least Square (GLS) (Yapono \& Situ, 2018)

Tabel 1. Hasil Pengujian Hipotesis

\begin{tabular}{|l|r|l|l|l|}
\hline Vareabel & coefficient & $\begin{array}{l}\text { Std.Er } \\
\text { ror }\end{array}$ & t.Statistik & Prob \\
\hline & & & & \\
\hline X1-Lev & -34.80 & 11.36 & -3.06160 & $\begin{array}{l}0.00 \\
4\end{array}$ \\
\hline X2-SIZE & 0.09596 & 0.73 & 0.131093 & $\begin{array}{l}0.89 \\
6\end{array}$ \\
\hline C & 16.8077 & 10.19 & 1.648130 & 0.10 \\
7
\end{tabular}

Sumber :Olah Data Eviews 2010

Tabel 1 Berdasarkan hasil Uji Simultan (Uji F), variabel independen secara bersama-sama mempengaruhi variabel dependen dengan nilai sig $0.014607<0.05$. oleh karena itu, dapat disimpulkan bahwa terdapat pengaruh yang signifikan antara leverage dan ukuran perusahaan terhadap nilai perusahaan. Berdasarkan uji parsial (Uji T), dapat diidentifikasin bahwa leverage berpengaruh negatif signifikan terhadap nilai perusahaan dengan nilai sig 0.0040 $<0.05$ dan t-hitung sebesar -3.061606 . 
Ukuran perusahaan tidak berpengaruh positif terhadap nilai perusahaan dengan nilai sig $0.8964>0.05$ dan t-hitung sebesar 0.131093 .

\subsection{Pengaruh Leverage terhadap nilai perusahaan}

Hipotesis pertama pada penelitian ini adalah Leverage berpengaruh posifit signifikan terhadap nilai perusahaan. Berdasarkan hasil hipotesis diatas, hipotesis pertama diterima. Angka leverage menunjukkan negatif dan signifikan sehingga leverage dapat menurunkan nilai perusahaan. Penggunaan leverage yang lebih besar dapat meningkatkan jumlah beban dan risiko yang harus ditanggung oleh perusahaan. Dengan kata lain ketika leverage mengalami peningkatan maka nilai perusahaan akan menurun. Leverage negatif disebabkan nilai ratarata leverage setiap tahun cukup tinggi, dan mengalami naik turun. Rasio yang baik terjadi ketika hutang dan modal seimbang. Hal ini menunjukkan bahwa perusahaan masih lebih banyak menggunakan komposisi hutang daripada uangnya, dan akibatnya nilai perusahaan menjadi berkurang (Etyy at. al, 2020).

Brigham dan Houston (2016) menyatakan bahwa leverage mencerminkan kemampuan perusahaan untuk memenuhi hutang jangka panjang yang ditunjukkan oleh proporsi modal ekuitas untuk menutupi. hutang. Dalam menilai suatu perusahaan, investor akan melihat tingkat hutangnya guna menilai sejauh mana perusahaan tersebut menggunakan uang yang telah dipinjamnya (Cheng \& Tzeng, 2011). Tingkat hutang perusahaan juga dapat menunjukkan apakah keuangan perusahaan itu sehat atau tidak, dimana hutang yang berlebihan umumnya menimbulkan masalah financial distress. Penggunaan utang dalam rasio yang wajar dan terkendali berpotensi meningkatkan bisnis dan nilai perusahaan sehingga menjadi sinyal positif bagi investor (Suwardika \& Mustanda, 2017)

\subsection{Pengaruh Ukuran Perusahaan (Size) Terhadap Nilai Perusahaan}

Hipotesis kedua dalam penelitian ini adalah ukuran perusahaan berpengaruh positif terhadap nilai perusahaan (PBV). Hipotesis ini ditolak berdasarkan hasil pengujian hipotesis diatas. Berdasarakan hasil regeresi diperoleh tidak ada pengaruh terhadap PBV, hasil ini tidak sesuai dengan teori yang ada, baik penelitian yang menyatakan size berpengaruh positif ataupun dengan pernyataan negatif.

\section{Grafik. 1 Total Aset 2018}

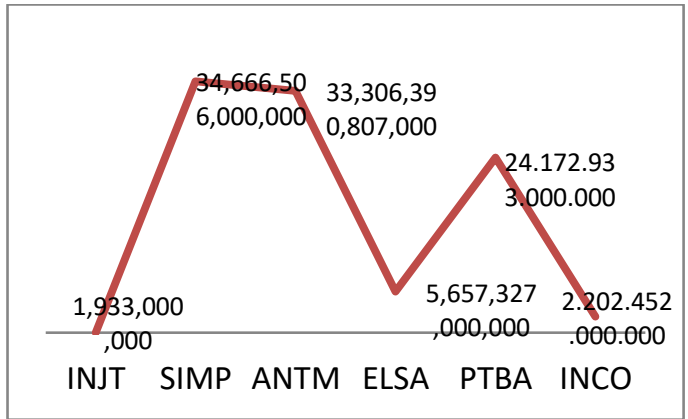

Sumber : Data diolah

Tidak adanya pengaruh vareabel size terhadap PBV adalah bisa disebabkan dengan ketersediaan data total aset perusahaan yang tidak sebanding antara satu perusahaan dengan perusahaan lainnya. Pada grafik 1 dapat dilihat, besar niai total aset antara perusahaan ANJT (PT Austindo Nusantara Jaya Tbk) sebesar 1.933.000.000 US\$, bandingannya jauh dengan SIMP (PT Salim Ivomas Pratama Tbk) dengan total aset 34.666.506.000.000 US\$. Oleh karena itu, 
vareabel size dalam penelitian ini tidak berpengaruh terhadap niai perusahaan (PBV).

Hasil dari pengujian pada variabel ukuran perusahaan terhadap Price to Book Value (PBV) tidak selaras dengan peneltian yang diakukan oleh (Reschiwati at al., 2020; Aggarwal \& Padhan, 2017; Etty at al., 2020) yang menyatakan bahwa, ukuran perusahaan berpengaruh signifikan terhadap Price to Book Value.

\section{PENUTUP}

\subsection{Simpulan}

Hasil penelitian menunjukkan bahwa, hanya variabel leverage yang mengikuti teori. Hasil ini sejalan dengan dugaan bahwa penggunaan leverage yang lebih besar dapat meningkatkan jumlah beban dan risiko yang harus ditanggung oleh perusahaan. Hal ini menunjukkan bahwa perusahaan masih lebih banyak menggunakan komposisi hutang daripada modalnya. Akibatnya nilai perusahaan menurun. Sedangkan vareabel ukuran perusahaan yang diukur dengan menggunakan tota aset tidak memiliki pengaruh terhadap PBV, ha ini dikarenakan ukuran perusahaan yang digunakan dalam penelitian berbeda jauh antar perusahaan yang satu dengan perusahaan yang lain. Sehingga untuk penetian yang selanjutnya bisa mempertimbangan terlebih dahulu keseimbangan data antar perusahaan yang akan digunakan dalam penelitian.

\section{DAFTAR PUSTAKA}

Reschiwati at al., (2020). Effect of Liquidity, Profitability, and Size of Companies on Firm Value. Journal Of Utopía y Praxis Latinoamericana vol. 25, núm. Esp.6, (Sept. 2020) hal 1-8.
Kalbuana at al., (2020). Liquidity Effect, Profitability Leverage to Company Value: A Case Study Indonesia. European Journal of Molecular \& Clinical Medicine ISSN 2515-8260 Volume 7, Issue 11, 2020

Hardinis (2019). Capital Structure and Firm Size on Firm Value Moderated by Profitability. International Journal of Economics and Business Administration Volume VII, Issue 1, 2019 pp. 174-191.

Etty at al., (2020). The role of internal factors in determining the firm value in Indonesia. Journal of Accounting 6 (2020) 665-670.

Nguyen, V. C., Nguyen, T. N. L., Tran, T. T. P., \& Nghiem, T. T. (2019). The Impact of Financial Leverage on The Profitability of Real Estate Companies: A study from Vietnam Stock Exchange. Journal of Management Science Letters, 9(Spceial Issue 13), 2315- 2326.

Aggarwal, D., \& Padhan, P. C. (2017). Impact of Capital Structure on Firm Value: Evidence from Indian Hospitality Industry. Journal of Theoretical Economics Letters, 7(4), 982-1000.

Yuniningsih, Y., Pertiwi, T. K., \& Purwanto, E. (2019). Fundamental Factor of Financial Management in Determining Company Values. Journal of Management Science Letters, 9(2), 205-216.

Ibrahim, U. A. (2020). Effect of Financial Leverage on Firm Value: Evidence From Selected Firms Quoted on the Nigerian Stock Exchange. European Journal of Business and Management, 12(3), 124-135.

Zaher (2020). Impact of finansial Leverage Size and Assetc Structure On Firm Value; Evidence From Industrial Sector, Jordan. International Business Research; Vol. 13, No. 1; 2020 ISSN 19139004 E-ISSN 1913-9012. 
Brigham, E. \& Houston, J. 2011. Essentials of Financial Management Eds 1. Buku, Jakarta, Salemba Empat.

Bouzzine, Y D, and R Lueg. 2020. "The Contagion Effect of Environmental Violations: The Case of Dieselgate in Germany." Business Strategy and the Environment 29(8): 3187-3202

Brown, L W, I Goll, A A Rasheed, and W S Crawford. 2020. "Nonmarket Responses to Regulation: A Signaling Theory Approach." Group and Organization Management 45(6): 865-91.

Shahrbabaki, A A et al. 2020. "Strategic Reactions to Information Content of Dividend Change: Applying Bcg Growth Share Matrix When Signalling Hypothesis Identified." Journal of Entrepreneurship and Sustainability Issues 8(2): 10-32.

Shou, Y, J Shao, W Wang, and K.-H. Lai. 2020. "The Impact of Corporate Social Responsibility on Trade Credit: Evidence from Chinese Small and Medium-Sized Manufacturing Enterprises." International Journal of Production Economics 230.

Wang, R, C.-J. Lee, S.-C. Hsu, and J.-H. Chen. 2020. "Preventing or Encouraging Illegal Activities by Construction Firms: Effects of Top Management Team Compensation and Aspiration-Performance Discrepancies." Engineering, Construction and Architectural Management.

Doukas, J A, and R Zhang. 2020. "Corporate Managerial Ability, Earnings Smoothing, and Acquisitions." Journal of Corporate Finance 65.

Javed, M et al. 2020. "A StakeholderCentric Paradigm Bids Well for the 'Business Case' - An Investigation through Moderated-Mediation Model." Corporate Social Responsibility and Environmental Management 27(6): 2563-77.
Cabaleiro-Cerviño, G, and A Burcharth. 2020. "Licensing Agreements as Signals of Innovation: When Do They Impact Market Value?" Technovation 98.

Baldick, H J, and S Jang. 2020. "Spending the Night with Strangers While Traveling? Examining the Antecedents of Shared Room Booking through Airbnb." International Journal of Contemporary Hospitality Management 13(12): 3853-71.

Moore, J. 2020. "Glamour among Value: $P / E$ Ratios and Value Investor Attention." Financial Management 49(3): 673-706.

Sujoko, \& Soebiantoro, U. (2017). Pengaruh Struktur Kepemilikan, Strategi Diversifikasi, Leverage, Faktor Intern dan Faktor Ekstern Terhadap Nilai Perusahaan (Studi Empirik Pada Perusahaan Manufaktur dan Non Manufaktur di Bursa Efek Jakarta). EKUITAS (Jurnal Ekonomi Dan Keuangan), 11(2), 236.

Horne, J.C.V. \& Wachowicz, Jr.J.M. 2009. Fundamentals of Financial Management, 13th Edition. Edinburgh Gate-England, Pearson Education Limited.

Brealey, R.A., Myers, S.C., Allen, F. 2011. Principles of Corporate Finance. Tenth Edition. New York, NY, McGraw-Hill Companies, Inc.

Suwardika, I. N Agus, dan I Ketut Mustanda. (2017). Pengaruh Leverage, Ukuran Perusahaan, Pertumbuhan Perusahaan, dan Profitabilitas Terhadap Nilai Perusahaan pada Perusahaan Properti. E-Jurnal Manajemen Universitas Udayana. 6(3), hal.1248-12

Brealey, R.A., Myers, S.C., Allen, F. 2011. Principles of Corporate Finance. Tenth Edition. New York, NY, McGraw-Hill Companies, Inc. 
Cheng, M.-C., \& Tzeng, Z.-C. (2011). The Effect of Leverage on Firm Value and How The Firm Financial Quality Influence on This Effect. World Journal of Management, 3(2), 3053.

Moore, J. 2020. "Glamour among Value: $P / E$ Ratios and Value Investor Attention." Financial Management 49(3): 673-706. 